\title{
Szülők, pedagógusok és diákok A heterogén célcsoportok megszólításának retorikai stratégiája
}

Mindig komoly retorikai kihívást jelent olyan összetett célcsoportok irányába hatékonyan kommunikálni, amelyek életkor, lakóhely és kommunikációs pozíció szempontjából is heterogének. Tanulmányomban egy hazai nonformális tehetséggondozó képzés toborzóanyagainak retorikai vizsgálatára vállalkozom. Az elméleti keretek kibontását követően arra keresem a választ, hogy miként változnak a tehetségprogram toborzási beszédeiben a meggyőzésre használt retorikai eszközök két változó, a horizontális (földrajzi elhelyezkedés) és a vertikális (célközönség) változó függvényében. A dolgozat alapjául szolgáló kutatás elsődlegesen arra fókuszált, hogy miben különböznek egymástól a toborzás különböző célcsoportjainak szóló kampánybeszédek.

\section{Bevezetés}

Doktori kutatásom egy hazai nonformális tehetséggondozó képzés, a Mathias Corvinus Collegium égisze alatt müködő Fiatal Tehetség Program meggyőzési stratégiáinak vizsgálatára irányul; célja a program verbális kommunikációjában megjelenő retorikai elemek, illetve eszközök azonosítása és hatásvizsgálata. A diszszertációs kutatás ezenkívül kitekint a vizuális hatáskeltő eszközökre is, valamint a tehetségprogram bevonási kampányának minden szereplöjét tekintetbe veszi. A jelen írásban azonban ennek a folyamatban lévő vizsgálatnak csupán egyetlen részkutatását tárgyalom: a szervezők kampánybeszédeiben elemzem a tehetségprogram bevonási stratégiáit.

A kutatás ismertetése előtt szükséges értelmezni azokat a főbb terminusokat, illetve fogalmakat, amelyek elsősorban más diszciplínákhoz (különösen az oktatáshoz és a pszichológiához) kötődnek.

A nonformális oktatás (vö. Memorandum 2000; Vargáné Subicz 2008: 2) az iskolai oktatást kiegészítő képzés, amely kevésbé hierarchizált, mint a formális oktatás, gyakorlati problémákra, élethelyzetekre fókuszál, valamint nem kormányzati, hanem elsősorban civil szervezet megvalósításában zajlik. Eszköztárát tekintve az élménypedagógia eszközkészletét alkalmazza, képzési tematikája multi-, illetve interdiszciplináris, és eltér a NAT kerettantervében előírt iskolai tananyagtól és oktatási módszerektől. Ez az eltérés abban mutatkozik meg a legszembetünőbben, hogy a nonformális képzések nem a NAT kimeneti és tantárgyi követelményeihez igazodnak. Így lehetőséget kínálnak például olyan kulcsterületeken történő szemléletformálásra és készségfejlesztésre, mint az egészségügyi tudatosság, a kritikus médiafogyasztás, a robotika, illetve olyan tantárgyközi kurzusok megvalósítására is, mint a müvészet és matematika összekapcsolása vagy egy történelmi korszak komplex (művészeti, történelmi, müvelödéstörténeti) áttekintése.

A toborzási beszéd a tehetségprogram bevonási stratégiájának részeként értelmezhető, meghatározott időszakban és meghatározott célközönség előtt elhangzó 
beszéd, amelynek célja a közvetett vagy közvetlen bevonás, illetve a csatlakozásra való biztatás, vagyis a meggyőzés. (A meggyőzés fogalmát a dolgozat 2. alpontja tárgyalja részletesebben.)

A jelen kutatás a Mathias Corvinus Collegium Fiatal Tehetség Programjának toborzási beszédeit vizsgálja. Ez a program 2015 óta biztosít nonformális tehetséggondozó képzést a Kárpát-medencei magyarság felső tagozatos diákjainak. ${ }^{1}$ A felmenő rendszerủ képzés jelenleg hat magyarországi (Szolnok, Budapest, Veszprém, Kecskemét, Miskolc, Pécs) és egy határon túli városban (Beregszász, Kárpátalja) működik, összesen 550 résztvevővel. Az élménypedagógiai eszközökkel dolgozó program oktatási fókuszában olyan tudományterületek állnak, amelyek a hagyományos iskolarendszerben nincsenek jelen, ugyanakkor a diákok mindennapi tapasztalataihoz szervesen kapcsolódnak.

\section{A kutatás elméleti háttere - a beszédfajták és a meggyőzés problematikája}

A jelen kutatásban az arisztotelészi beszédfajta-felosztás alapján vizsgálom a bevonási beszédek által alkalmazott meggyőzési stratégiákat.

\subsection{A beszédfajták kérdése}

Arisztotelész Rétorikájában (1. 3. 135b) a beszédeket müfajok szerint osztályozza: megkülönböztet törvényszéki (genus iudiciale), tanácsadó (genus deliberativum) és bemutató beszédet (genus demonstrativum). Ahogy Adamikné Jászó Anna (2013: 78-9) rámutat, e beszédfajták nem egzakt, egymástól független kategóriák, hanem átjárható, egymással gyakorta kölcsönhatásba lépő müfajok. Kifejezetten ritka a tiszta beszédtípus, ezek sajátosságai jellemzően keverednek, némelyik retorikaszerző ezért vegyes típusú beszédet is elkülönít. A beszédfajta meghatározásában ezért elsődlegesen a beszéd célját szükséges figyelembe venni (Adamikné Jászó 2017: 27).

E megállapítás a kutatásom szempontjából azért különösen jelentős, mert - ahogy később rámutatok - a vizsgált kampánybeszédek sem sorolhatók be egyértelmüen egyik arisztotelészi kategóriába sem: a legtöbb esetben egyaránt hordozzák a tanácsadó és a bemutató beszéd jellegzetességeit.

Arisztotelész nyomán a szakirodalom a beszédfajták felosztása során több szempontot vesz figyelembe (vö. Adamik-A. Jászó-Aczél 2004: 156): a beszéd idősíkját, a retorikai szituációt, az alkalmazott érvtípusokat, illetve az implikált retorikai cél(oka)t.

Ezen szempontok szerint a bemutató beszéd a jelenre koncentrál, a retorikai szituáció része, hogy a beszélő egy ismeretlen témakört ismertet meg a hallgatósággal, eszköze a pozitív jellemzés, illetve a konkurencia bírálata, retorikai célja pedig a meggyőzés.

A tanácsadó beszéd jövőorientált, retorikai szituációja közös előismeretekből fakad, érvelése a hasznosság, a helyesség megállapítását szolgálja, célját tekintve pedig ugyanúgy meggyőzni kíván.

1 Lásd: fit.mcc.hu weboldal szerint (utolsó hozzáférés: 2019. aug. 30.). 
A két említett beszédfajta föbb sajátosságait, illetve különbségeit az alábbi, 1. táblázat foglalja össze:

1. táblázat. A bemutató és a tanácsadó beszéd

\begin{tabular}{|l|l|l|l|l|}
\hline Beszédfajta & Idôsík & Retorikai szituáció & Érvtípusok & Retorikai cél \\
\hline Bemutató & Jelen & $\begin{array}{l}\text { Ismeretlen témakör } \\
\text { megismertetése }\end{array}$ & $\begin{array}{l}\text { Pozitív jellemzés + kritika a } \\
\text { konkurenciára vonatkozóan }\end{array}$ & $\begin{array}{l}\text { Meggyốz: } \\
\text { Észlelésre, } \\
\text { véleményre, attitũddre } \\
\text { hatásgyakorlás }\end{array}$ \\
\hline Tanácsadó & Jövổ & $\begin{array}{l}\text { Közös elổismeretekre } \\
\text { építés }\end{array}$ & $\begin{array}{l}\text { Hasznosságra, helyességre } \\
\text { vonatkozók }\end{array}$ & $\begin{array}{l}\text { Meggyốz: } \\
\text { Cselekvésre késztet }\end{array}$ \\
\hline
\end{tabular}

\subsection{A meggyőzés fokozatai}

A fent említett szempontrendszer értelmezése, illetve alkalmazása során különösen fontos a meggyőzés pontos meghatározása, ugyanis míg egy bemutató beszéd elsősorban az észlelésre és a hallgatóság véleményének befolyásolására épít, a tanácsadó beszéd nagyobb valószínüséggel vált ki valamilyen konkrét cselekvést is a beszélőböl.

A meggyőzést el kell különíteni az úgynevezett retorikai müveletektől - így például a rábeszéléstől (azaz a manipulációtól, vö. Adamik [szerk.] 2010: 747-51) és a kényszerítéstől. A rábeszélés esetében a rétor tudatosan visszaél azzal, hogy a hallatóság tudásához képest többletinformációkkal rendelkezik, míg a kényszerítés során (verbális és/vagy fizikai) erőszakkal kívánja kiváltani a szándékolt hatást. Ezzel szemben a meggyőzés a hallgatósággal interakcióban, konszenzuálisan történik (vö. Burke 1967: 43).

Az affektív pszichológia (pl. Hovland-Harvey-Muzafer 1957: 244-52) a meggyőzés négy lépcsőjét különbözteti meg; ezen szintek mindegyike fontos lehet az alkalmazott nyelvészeti szempontú kutatások számára is.

Az első fokozat esetében a beszélö/rétor az észlelésre hat: irányítja a hallgatók észlelési fókuszát, illetve törekszik arra, hogy megváltoztassa a percepciójukat.

A második szint a vélemény megváltoztatása, vagyis a tudat átszervezése olyan módon, hogy a hallgatóság valamely elvet, nézetet elfogadjon (vö. Szabó 1998: 68). Burke (1967: 43) felfogása szerint ez esetben egy olyan szimbolikus cselekvésröl van szó, amely a megértés közös módját hozza létre a rétor és a hallgatóság között.

A meggyőzés harmadik lépcsője az affiliáció/attitüd megváltoztatására irányul; ez a folyamat attitüdkialakításként, attitüdmegerősítésként, illetve a beállítódás megváltoztatásaként értelmezhető. (Az attitüdöt Aronson [1995: 167-91] nyomán egyszerre tekintem értékítéletnek és érzelmi komponensnek.)

A negyedik szinten a meggyőzés cselekvésre késztet. A bemutató beszéd tipikusan nem eredményez azonnali cselekvést, hanem cselekvéshez való hozzáállást vált ki, ha a hallgatóság számára a megfelelő idő elérkezik. Perelman szerint épp ezért e beszédfajta célja az egyetértés kialakítása olyan értékekben, amelyek a cselekvést irányítják a jövőben (Perelman 2018: 38). 
A Fiatal Tehetség Program bevonási stratégiájának esetében mind a négy meggyözési szint aktiválódik: a tehetségprogram toborzási beszédei felhívják a figyelmet a képzésre, a bekapcsolódás lehetőségére, törekszenek arra, hogy értékközösséget, egyetértést hozzanak létre a rétor és a hallgatóság között, pozitív érzelmi viszonyulást igyekeznek kialakítani a programmal kapcsolatban, valamint cselekvésre (vagyis jelentkezésre) ösztökélik a célcsoportot.

Milyen retorikai eszközök kapcsolódnak a vázolt négy meggyőzési szinthez? Arisztotelész logikai, etikai és páthoszból eredeztethető (logosz, éthosz, páthosz) meggyözési utakat különít el (vö. Adamik-A. Jászó-Aczél 2004: 30). Kutatásomban ezek vizsgálatára, illetve csoportosítására vállalkozom. Fontos kiemelni ugyanakkor, az arisztotelészi retorika nem csupán statikus, egyirányú megközelítéssel él, így ebből kiindulva a meggyözést dinamikus, a diskurzus által létrehozott és abban formálódó, többirányú, kölcsönös folyamatként azonosítják a modern retorikák is (lásd pl. Perelman 2018; Burke 1967). Ezt azért lényeges hangsúlyozni, mivel az arisztotelészi retorikát az idők folyamán egyre szükebben értelmezték, ékesszólásra, alakzatkutatásra vagy éppen beszédtechnikára redukálták. Miközben Arisztotelésznél az érvelések, a beszédstílusok, a beszédszerkesztés és az érzelmek vizsgálatának elmélete is a retorika tárgykörébe tartozott, épp ezért Perelman és Burke a retorika eredeti, tágan vett arisztotelészi értelmezéséhez nyúlnak vissza, alkalmazott kommunikációtannak tekintve a retorikát. Kutatásom során ezt a felfogást is igyekszem érvényesíteni.

A meggyőzési utak vizsgálatakor az érvtípusok megjelenését, elkülöníthetőségét is elemzem. Az arisztotelészi retorika nyomán külső és belső érveket különböztethetünk meg, a külső érvek a szövegvilágon túli valóságból származtatott érvek, statisztikák, tekintély, maximák, precedens, jelek; míg a belső érveket általános és specifikus érvforrásokra oszthatjuk. Általános érvforrásokhoz számítjuk a meghatározáson, összehasonlításon, viszonyokon, körülményeken alapuló érveket, míg a specifikus érvforrások a beszédtípusokhoz kapcsolódnak.

A retorika átszövi az összes kommunikációs folyamatot, hiszen lényege a hallgatóság meggyőzése, figyelmének irányítása, tudatának formálása. Ahogy Kenneth Burke (1967: 172) fogalmaz: „Ahol meggyőzés van, ott retorika is van. Ahol »jelentés « van, ott meggyőzés is van" (saját ford. - C. M.). ${ }^{2}$

\section{Kutatási kérdések}

Doktori kutatásomban arra keresem a választ, hogy miként változnak a tehetségprogram toborzási beszédeiben a meggyőzésre használt retorikai eszközök a horizontális és a vertikális változók (vagyis a földrajzi elhelyezkedés és a [cél]közönség) függvényében. A disszertációban tehát - a földrajzi elhelyezkedés lehetséges hatásainak feltárása érdekében - külön is megvizsgálom a képzés különböző oktatási helyszínein elhangzott kampánybeszédeket, amelyeket a program munkatársai tartottak (Beregszászban, Budapesten, Miskolcon, Pécsett, Szolnokon és Veszprémben). A beszédek célközönségét a pedagógusok, a szülők, valamint a negyedik osztályos általános iskolás diákok alkotják.

2 „Wherever there is persuasion, there is rhetoric. And wherever there is 'meaning' there is persuasion." 
A jelen dolgozatban bemutatott részkutatás a fentebb vázolt elméleti keretben azt a kérdést vizsgálja, hogy változnak-e, és ha igen, miként változnak a meggyőzés eszközei a toborzás különböző célcsoportjainak szóló kampánybeszédekben. Két változót vizsgáltam: a célközönséget (szülők, esetenként pedagógusok, illetve diákok), amit nevezhetünk vertikális változónak, és a képzések helyszínét, amit horizontális változónak nevezhetünk.

\section{A kutatási korpusz}

Dolgozatom korpuszát 27 toborzási kampánybeszéd alkotja; a kutatás jelen fázisában ezek elemzésére vállalkoztam. A tehetségprogram regionális munkatársai (minden régióban egy személy) állnak kapcsolatban egy-egy régió diákjaival és pedagógusaival, többéves gyakorlattal rendelkeznek a toborzási kampányokban, és a célközönség ismeretén túl gyakran pedagógusi tapasztalatokkal is bírnak. Az általuk tartott beszédek formátumukat tekintve félig kötött retorikai alkotások, amelyek bár azonos kulcsszavakon és sablonokon alapultak, igazodtak a célközönséghez, a helyszínhez, illetve a felmerülő kérdésekhez, emellett tartalmaztak a hallgatósággal folytatott interakciókhoz kapcsolódó elemeket is (lásd később). A beszédekhez a hallgatóság a beszéd közben, közbevetve és utólag is feltett kérdéseket, és ezekre a rétor válaszolt. Ezek a szövegek is a vizsgált korpusz részét képezték. Az egyes rögzített (és elemzett) beszédek ideje mindezeket figyelembe véve 7 és 19 perc között volt; a felvételek átlagos hossza 11 perc, a teljes hanganyag 295 perc hosszúságú.

Hat beszéd a szülői közösséget célozta meg, huszonegy pedig közvetlenül a negyedik osztályos általános iskolásoknak szólt, az ő bevonásukra törekedett. A célközönség heterogenitása abból fakad, hogy a képzés szervezői egyfelől fontosnak tartják a diákok figyelmének felkeltését, érdeklődésük megnyerését, másfelől ugyanakkor a csatlakozás ebben az életkorban csak szülői beleegyezéssel történhet. Emellett a pedagógusok szimpátiájának megnyerése segíthet abban, hogy a program híre eljusson a szülöi közösségekhez.

Földrajzi megoszlást tekintve öt budapesti (köztük egy szülőknek szóló), hat beregszászi, négy miskolci (köztük két szülőknek szóló), két pécsi, négy szolnoki (egy szülőknek szóló) és hat veszprémi (két szülőket érintő) beszédet rögzítettem és vizsgáltam meg.

A beszédek vizsgálatakor egyrészt a szövegek szerkezetét vázoltam fel, másrészt a bennük előforduló hatáskeltő eszközökre, illetve azok használatára fókuszáltam.

\section{A beszédszerkezetek összehasonlítása}

A beszédek felépítésének elemzésekor az arisztotelészi klasszikus felosztást vettem alapul, amelyet Adamikné Jászó Anna (2013) ismertet és egészít ki összefoglaló munkájában. A kutatás során világossá vált, hogy a beszédnek az antikvitásban felvázolt szerkezete jól jellemzi a mai toborzóbeszédeket is: az ókorban leírt struktúrák megfeleltethetők a modern szövegek egyes beszédrészeinek.

A beszédek szerkezetének vizsgálata során a diákoknak, illetve a szülőknek vagy pedagógusoknak szóló beszédek között az egyes beszédrészek funkciójában és - 
ezzel együtt - a különböző funkciókhoz kapcsolódó retorikai eszközökben is több eltérés vált megfigyelhetővé.

A bevezetés a diákoknak szóló beszédekben bemutatkozást és rétori kérdéseket foglalt magába (pl. „Ki hallott már a robotikáról? Ki szeretne kísérletezni egy laboratóriumban?"). Azokban az esetekben azonban, amikor a hallgatóságot szülők vagy pedagógusok alkották, a beszédnek ezen szerkezeti egységében a bemutatkozást követően a beszéd témaköreinek felvázolása, illetve a közös érdek hangsúlyozása (pl. „A Program egyedülálló fejlődési lehetőséget kínál a diákok számára”) állt előtérben. Funkcióját tekintve a bevezetés tehát mindkét esetben a témakijelölést (docilitas) és a figyelem felkeltését (attentio) szolgálta, ugyanakkor a szülőknek szóló beszédek esetében a jóindulat elnyerésére irányuló törekvés (captatio benevolentiae) is tetten érhetö volt benne.

Az elbeszélés mindkét csoport esetében a program bemutatását célozta, ugyanakkor a meggyőzés érvtípusainak arányát tekintve különbségek is kimutathatóvá váltak: a diákoknak szóló beszédekben több volt a páthoszból eredeztethető érv (a páthoszt az eredeti arisztotelészi értelmében használom, vagyis bármiféle érzelemre vonatkoztatva, nem csak a hétköznapi 'magasztos', 'patetikus' értelemben). A felnőttek meggyőzésére törekvő szövegekben pedig döntően a logoszra ható, illetve az éthoszból fakadó érvek voltak megfigyelhetők. Például:

- Diákoknak:

(1) Kaland, közösség, kihívás vár Rátok, ahol a tanulás csupa-csupa játék és élmény. Legyen szó a robotok építéséről vagy az életmentésről.

- Felnőtteknek:

(2) A Mathias Corvinus Collegium által müködtetett Fiatal Tehetség Program személyiségfejlődésben bekövetkező eredményeit több pszichológiai vizsgálat is alátámasztja, illetve dr. Bagdy Emőke professzor asszony is megerősítette a képzés fejlesztő hatását.

A felnőtteket célzó beszédekben ezenkívül külső érvek - tekintélyre ható érvek, példák, statisztikák és viszonyítások - is megjelentek. Például:

(3) A hatásvizsgálat alapján a gyermekek többségénél szignifikánsan változik az iskolai teljesítmény is, illetve az osztályközösségben betöltött szerep is kedvezően változik.

A tétel funkciója a jelentkezés szükségességének hangsúlyozása; emellett a szülök meggyőzésére irányuló szövegek esetében ez a beszédrész a hallgatói visszacsatolásoknak is teret biztosít.

A bizonyítás a diákoknak szóló beszédek esetében a programhoz való csatlakozással járó előnyök felsorolására koncentrált, míg a szülők esetében a hosszú távú eredményesség bemutatását foglalta magában. Például: 
(4) A Programot elvégző diákok pszichoszociális fejlődése és megküzdési stratégiái meghaladják a kortársaknál megfigyelhető mértéket.

Ebből az aspektusból a diákoknak szóló beszéd a bemutató beszéd (genus demonstrativum) müfajához közelít, míg a jövőbe tekintő, felnőtteknek szóló bizonyítás a tanácsadó beszéd (genus deliberativum) beszédfajta sajátossága.

Mindezek mellett a befejezés funkciója is kettős: a szülők esetében ez a beszédrész a cselekvésre sarkallás (,Jelentkezzen most!”), míg a diákoknál az érzelmi bevonás eszköze (,Te se maradj ki egy szuper lehetőségből, egy szuper csapatból!’).

A különböző célcsoportoknak szóló beszédek szerkezetét az alábbi, 2. táblázat mutatja be.

2. táblázat. Az egyes beszédfajták összehasonlítása

\section{BESZÉDSTRUKTÚRÁK ÖSSZEHASONLÍTÁSA}

\begin{tabular}{|c|c|c|}
\hline Beszédrész & Diákoknak szóló & Szülőknek, pedagógusoknak szóló \\
\hline Bevezetés & $\begin{array}{l}\text { Bemutatkozás, rétori kérdések } \\
\text { (docilitas, attentio) }\end{array}$ & $\begin{array}{c}\text { Bemutatkozás, témavázlat, } \\
\text { közös érdek hangsúlyozása } \\
\text { (docilitas, captatio benevolentiae) }\end{array}$ \\
\hline Elbeszélés & $\begin{array}{l}\text { A program bemutatása } \\
\text { (páthosz) } \\
\text { Lehetôségek bemutatása, } \\
\text { tevékenységei kör }\end{array}$ & $\begin{array}{c}\text { A program bemutatása } \\
\text { (ethosz, logosz) } \\
\text { Külső érvek - példák, statisztikák, } \\
\text { tekintély } \\
\text { viszonyrendszer }\end{array}$ \\
\hline Tétel & Jelentkezés szükségessége & $\begin{array}{c}\text { Jelentkezés szükségessége - } \\
\text { visszacsatolás }\end{array}$ \\
\hline Bizonyítás & $\begin{array}{l}\text { Előnyök felsorolása } \\
\text { genus demonstrativum }\end{array}$ & $\begin{array}{l}\text { Hosszú távú eredményesség } \\
\text { genus deliberativum - jövőbe tekintő }\end{array}$ \\
\hline Befejezés & meggyőzés - érzelmi bevonás & meggyôzés - cselekvésre késztetés \\
\hline
\end{tabular}

Jól látható, hogy miközben mindkét célcsoportnak szóló beszédtípus jól elkülöníthetően a klasszikus szerkezeti egységek szerint épül fel, az egyes egységeken belül megfigyelhetö tartalom, érvrendszer eltér egymástól. A bevezetésben az érdeklődés felkeltése mellett a diákok mozgósító, cselekvési lehetőséget felkínáló, érzelmekre apelláló kérdéseket kapnak, míg a felnőttek számára a logikára ható, józanabb megfontolás, a hosszú távú közös érdek hangsúlyozása fogalmazódik meg. Ugyanígy: a program bemutatása a gyerekeket az adott tevékenység pillanatnyi érdekességére építve, érzelmileg vonja be, míg a felnőttek számára a logikai úton történő meggyőzés az elsődleges. Jól látható, hogy a gyerekeknél a jelenidejüség, a felnőtteknél pedig a jövő, a hosszú távú előnyök hangsúlyozása jelenik meg. A célcsoportok lehetőségei miatt a gyerekeknél a lelkesítés, a felnőtteknél a konkrét cselekvésre való felhívás zárja a beszédet. 


\section{A meggyőzési módok vizsgálata}

A beszédrészek sajátosságainak ismertetése után a következökben az adott toborzóbeszédekben előforduló meggyőzési módok feltárására fókuszálok. Ezek leírásához alapvetően ugyancsak az arisztotelészi felosztást veszem alapul - vagyis az éthoszból eredő, a logoszra ható és a páthoszból fakadó meggyőzési eszközöket vizsgálom a szóban forgó beszédekben.

\subsection{Az éthosz}

Az éthosz meggyőző ereje a szónok emberi, szakmai hitelességéből eredeztethető, amely a hallgatóság előzetes tudása révén aktiválódik. Amennyiben a szakmai hitelesség (és ennek elismertsége a hallgatóság előzetes tudásában) hiányzik, fennállhat a körbenforgó érvelés (petitio principii) veszélye. Ezzel összhangban a rétorok a vizsgált esetekben beszédeiket bemutatkozással nyitották, amelyben - különösen, amikor felnőtt célközönséghez szóltak - saját szakmai életútjukat vázolták fel, illetve a képzésben betöltött szerepüket hangsúlyozták.

Ugyancsak itt említhetô a tiszteletre alapozó (ad verecundiam) érvtípus; az ilyen érvekkel a rétor transzformálhatja az éthosz meggyőző erejét valamely távoli, jelen nem lévő, közismert tekintélyszemély(ek) irányába. Ez az érvtípus is elsősorban felnőtt célközönség esetében fordult elő. Ilyen eseteket szemléltet az (5) és a (6) példa:

(5) Munkánk sikerét több ezer nálunk végzett diák, neves hazai és külföldi vendégprofesszorok által tartott kurzusok, számos tudományos konferencia és tanulmánykötet jelzi.

(6) Oktatási programunkba olyan szaktekintélyek kapcsolódtak be, mint Maróth Miklós és Romsics Ignác akadémikusok, John Lukács történészprofesszor.

A továbbiakban érdemes lehet vizsgálni azt is, hogy a hivatkozott tekintélyszemélyek kiválasztását hogyan befolyásolják a regionális tényezők. Kutatásom erre ez esetben részletesen nem tért ki, ugyanakkor az elemzett beszédek feldolgozása során felfigyeltem rá, hogy míg Beregszászban és Miskolcon elsősorban magyar szaktekintélyekre (Bagdy Emőke, Kádár Annamária) hivatkoztak a rétorok, Budapesten főként nemzetközi szaktekintélyeket (David Venter politikai szakértő, John Lukács történész) említettek.

\subsection{A logosz}

A logoszra ható meggyözés egyik eszközét a csonka szillogizmusok (enthümémák) alkotják: ezekben az esetekben miután a rétor vázolja a premisszákat, a konklúziót a hallgatóságnak kell levonnia. Így a hallgatók mélyebben bevonhatók a gondolkodási folyamatba, és ezzel együtt (amennyiben a következtetési folyamataik során nem 
merülnek fel akadályok) az ilyen érvelés hatásosabb, mint ha a konklúziót is a rétor fogalmazná meg. Erre az érvelési módra példa a (7) és a (8) megnyilatkozás:

(7) Hiszünk abban, hogy értékálló fejlődés csak hosszú távon érhető el (P1), ezért Collegiumunk a gyakorlatba ültette a lifelong learning vízióját. (P2).

Konklúzió: a Collegium értékállóan fejleszt.

(8) Minél korábbi életszakaszban sikerül a kiemelkedő képességü gyermekek tudatos fejlesztését megkezdeni, annál nagyobb hatékonysággal bontakoztatható ki az egyéni érdeklődésük. (P1)

E megfontolások jegyében indítottuk útjára és fejlesztjük folyamatosan képzésrendszerünk legújabb elemét, a Fiatal Tehetség Programot. (P2) Konklúzió: nagy hatékonysággal fejleszt.

A szülők, illetve a pedagógusok meggyőzésének egy lehetséges eszköze ezenkívül az belső, általános érvforrásként értelmezhető definíciók alkalmazása (9), valamint az ellentétpárok megfogalmazása (10):

(9) a felső tagozatos általános iskolásoknak biztosít ingyenes, komplex szemléletü tehetséggondozást [...] A FIT Programra jellemző a nagyfokú szellemi szabadság és függetlenség.

(10) az iskolai oktatáson túlmutató, ugyanakkor a mindennapi világunkhoz sok szállal kapcsolódó foglalkozásokat.

Belső, általános érvforrások között az összehasonlítás is megjelenik egy idézett, a Programban részt vevő diák véleményében:

(11) A FIT nem olyan, mint az iskola, itt a tanulás is játék.

Ok-okozati viszonyokon alapuló érvek is megjelennek, a képzés szabad szellemi kereteiből következik a fiatalokra gyakorolt hosszú távú pozitív hatás, ahogy az elemzett szöveg fogalmaz:

(12) A FIT Programra jellemző a nagyfokú szellemi szabadság és függetlenség. Képzésünk által diákjaink érdeklődő, széles látókörü, nyitott gondolkodású fiatalokká válnak

\subsubsection{Ad-típusú érvek a logosz meggyőző erejének szolgálatában}

A vizsgált anyagban a logoszra ható érvek között megjelenik a régiségre való hivatkozás (argumentum ad antiquitatem) is, amely - a korábban említettekhez hasonlóan - elsősorban a felnőtt célközönségnek szóló beszédekben fordult elö: 
(13) A Mathias Corvinus Collegium (MCC) több mint 20 éve foglalkozik egyetemista és középiskolás diákok tehetséggondozásával.

Az újszerüségre építő érvelés (argumentum ad novitatem) ugyanakkor a diákoknak és a felnőtteknek szóló beszédekben egyaránt jelen volt:

(14) 2015-ben oktatási kínálatunkat bővítve felső tagozatos általános iskolásoknak is elindítottuk új tehetséggondozó képzésünket.

(15) Korszerü infokommunikációs eszközök (tabletek, laptopok, okostelefonok) is szerves részei oktatási gyakorlatunknak

A szülők meggyőzését célzó beszédek esetében megjelenik az ingyenesség mint érv (az argumentum ad crumenam) is - adott esetben a képzés ingyenességét hangsúlyozva.

\subsection{A páthosz}

A páthosz esetében érzelmi hatáskeltésről beszélhetünk. Az erre épülő érvek elsősorban a diákközönségnek tartott beszédekben jutottak érvényre.

A páthoszhoz kapcsolhatók például azok a vizuális hatáskeltő elemek, amelyek a beszédeket kísérő prezentációban és kisfilmben jelentek meg: olyan képek és filmek említhetők itt, amelyek a közös identitást és/vagy a program hangulatát tükrözték, illetve vizuálisan megjelenítették azokat az élménypedagógiai eszközökön alapuló kurzusokat, amelyek a programba belépő diákokra várnak.

Az érzelmi hatáskeltés eszközeinek tekinthetők továbbá a toborzóbeszédek elején elhangzó (tipikusan az érzelmi bevonódást elösegítő) költői kérdések is, amelyek elsősorban ugyancsak a diákok figyelmének felkeltését célzó beszédekben fordultak elö. Például:

(16) Kísérleteznél egy igazi laborban? Építenél robotokat vagy drónokat? Kipróbálnád, hogy dolgoznak a mentősök? Érdekel a bankok titokzatos világa? Egy jó közösségre vágysz, ahol játszva tanulhatsz?

A szülök és pedagógusok felelősségvállalására, elkötelezettségére, vállalt szerepére, énképére építenek:

(17) Célul tüztük ki, hogy az érintett szülőkkel és pedagógusokkal együtt segítsük a gyermekek kibontakozását, az egyéni érdeklődési területek felfedezését és a későbbi tudatos pályaválasztást.

Mivel a stílus is érvelő erővel bír, így a stílusalakzatok is állhatnak a meggyőzés szolgálatában, például az ismétlés is lehet az érzelmi hatáskeltés eszköze. Terjedelmi korlátok miatt nem nyílik lehetőség az összes stíluseszköz részletes bemutatására, ugyanakkor az ismétlést - gyakorisága folytán - érdemes kiemelni. Különösen gyakori a közösség szó mind a diákoknak, mind a felnőtteknek szóló beszédek- 
ben (esetenként összetételek, jelzős szerkezetek részeként is, pl. értékközösség, alumniközösség, közösségi élmények, MCC-s közösség).

A használt kifejezések stílusértéke is kiválthat érzelmi hatást, a bizalmas stílusértékü kifejezések (titokzatos, rejtelmei) a közvetlenségnek, a bensőséges kapcsolat megteremtésének eszközei:

(18) Képzéseink napjaink legizgalmasabb területeit fogják át, legyen szó a pénz titokzatos világáról, a drónok müködéséről, a kortárs építészet vagy éppen a laborok rejtelmeiröl.

\section{7. Összefoglalás}

A beszédfajták vizsgálata rávilágított arra, hogy a feldolgozott toborzóbeszédek egyaránt tükrözik a tanácsadó és a bemutató beszéd jellegzetességeit, ugyanakkor a diákoknak szóló beszédek inkább a bemutató, míg a pedagógusoknak és szülőknek szólók inkább a tanácsadó beszédfajtához állnak közel.

A beszédstruktúra elemzése arra mutatott rá, hogy a beszédrészek a célközönséghez igazodva más-más funkciókat tölthetnek be. Emellett az adatokból kirajzolódott az is, hogy a befejezés sajátosságainak feltárása segíthet a müfaji kérdések eldöntésében.

A meggyőzés különböző módozatait vizsgálva megállapítható, hogy az etikai alapú és az előzetes ismeretekre építő érvek elsősorban a felnőtteket (szülőket és pedagógusokat) szólítják meg.

A logikai úton történő meggyőzés eszközei, illetve az olyan külső érvforrások, mint a tekintély vagy az olyan belső, általános érvforrások, mint a definíció, ugyancsak a tanárok és a szülők befolyásolására szolgálnak.

Az érzelmi hatás kiváltására szolgáló retorikai eszközök közül kiemelkednek a vizuális eszközök, illetve a cselekvési lehetőségek felkínálása és a kortársak véleményei, amelyek elsősorban a diákok megszólításában játszanak szerepet. A korpusz vizuális retorikai elemzése egy új perspektívát jelent, amely egy új vizsgálat része lehet.

\section{SZAKIRODALOM}

Adamikné Jászó Anna 2013. Klasszikus magyar retorika. Holnap Kiadó, Budapest.

Adamikné Jászó Anna (szerk.) 2017. Pécseli Király Imre: Bevezetés a retorikába két könyvben. Ford. Constantinovitsné Vladár Zsuzsa. Trezor Kiadó - Anyanyelvápolók Szövetsége, Budapest.

Adamik Tamás - A. Jászó Anna - Aczél Petra 2004. Retorika. Osiris, Budapest.

Adamik Tamás (szerk.). 2010. Retorikai Lexikon. Kalligram, Pozsony.

Arisztotelész 1982. Rétorika. Ford. Adamik Tamás. Gondolat, Budapest.

Aronson, Elliot 1995. A társas lény. Ford. Erős F. Közgazdasági és Jogi Könyvkiadó, Budapest.

Burke. Kenneth 1967. Rhetoric Of Motives. University Of California Press, Berkeley.

Hovland, C. I. - Harvey, O. J. - Sherif, M. 1957. Assimilation and contrast effects in reactions to communication and attitude change. The Journal of Abnormal and Social Psychology. 55/2: 244-52. https://doi.org/10.1037/h0048480 
Memorandum az egész életen át tartó tanulásról 2000. Európai Közösségek Bizottsága, Brüsszel, 2000. október 30. 1832.

Perelman, Chaim 2018. A Retorika Birodalma. Ford. Majoros H. Tinta Könyvkiadó, Budapest.

Szabó István 1998. Bevezetés a szociálpszichológiába. Nemzeti Tankönyvkiadó, Budapest.

Vargáné Subicz Beáta 2008. A nem formális tanulás célja, lehetőségei, színterei és eszköze.

NSZFI munkaanyag: http://kepzesevolucioja.hu/dmdocuments/4ap/2_1896_013_10103

0.pdf (utolsó hozzáférés: 2019. jún. 1.).

\section{Constantinovits Milán \\ doktorandusz}

ELTE BTK Nyelvtudományi Doktori Iskola

Alkalmazott Nyelvészet Doktori Program

https://orcid.org/0000-0002-0883-0485

\section{SUMMARY}

Constantinovits, Milan

\section{Parents, teachers and students - The rhetorical strategy of invocation of a heterogeneous audience}

The aim of this paper is to analyse how the three elements of classical persuasion: ethos, pathos, and logos work in a unique speech genre. The campaign speeches of a Hungarian nonformal educational institution, the Young Talents Programme of Mathias Corvinus Collegium, aim to convince a heterogeneously targeted audience: parents, teachers and students at the same time about the advantages of the programme.

The speeches examined show characteristics of two speech genres simultaneously: the deliberative genre (genus deliberativum) and the epideictic genre (genus demonstrativum). The analysis comes to the conclusion that ethos-based persuasion within the speeches and the logical devices of persuasion principally attempt to involve the adult audience, while pathosbased elements of the speeches are mostly targeted at the students.

Keywords: rhetoric, non-formal education, persuasion, ethos, pathos, logos, speech genres. 